Ambiente \& Água - An Interdisciplinary Journal of Applied Science
ISSN 1980-993X - doi:10.4136/1980-993X
www.ambi-agua.net
E-mail: ambi.agua@gmail.com

\title{
Characterization of controlled landfill leachate from the city of Guaratinguetá - SP, Brazil
}

\author{
ARTICLES doi:10.4136/ambi-agua.2136
}

Received: 21 May 2017; Accepted: 07 Jan. 2018

\author{
André Luis de Castro Peixotoㅜ; Rodrigo Fernando dos Santos Salazar ${ }^{2 *}$; \\ Jayne Carlos de Souza Barboza ${ }^{3}$; Hélcio José Izário Filho ${ }^{3}$ \\ ${ }^{1}$ Instituto Federal de Educação, Ciência e Tecnologia de São Paulo (IFSP), Capivari, SP, Brasil \\ Departamento de Química. E-mail: alcpeixoto@ifsp.edu.br \\ ${ }^{2}$ Universidade de Cruz Alta (UNICRUZ), Cruz Alta, RS, Brasil \\ Centro de Ciências da Saúde e Agrárias (CCSA), Departamento de Engenharia Ambiental e Sanitária \\ E-mail: r.f.s.salazar@gmail.com \\ ${ }^{3}$ Escola de Engenharia de Lorena (EEL-USP), Lorena, SP, Brasil \\ Departamento de Engenharia Química.E-mail: jayne@dequi.eel.usp.br, helcio@ dequi.eel.usp.br \\ ${ }^{*}$ Corresponding author
}

\begin{abstract}
This research evaluated the physicochemical parameters of a leachate sample from a controlled landfill in the city of Guaratinguetá-SP. The evaluation was conducted using spectrometric and spectrophotometric methods in order to assess the formation of persistent compounds. The selection of parameters was based on the CETESB Article 18 and CONAMA 357/05 Article 34, as well as organic characterization methods, such as FTIR, NMR (1H-NMR, 13C-NMR and APT), GC-MS, molar mass distribution and elemental analysis (CHN). Chemical and physical stability were also verified. The ammoniacal nitrogen concentration is 20 times greater than tolerance limit established by law $\left(20 \mathrm{mg} \mathrm{L}^{-1}\right)$. The $\mathrm{Ba}$ and $\mathrm{Ni}$ presented concentrations above those permitted by the legislation (CETESB Article 18 and CONAMA 357/05 Article 34). Those values of chemical oxygen demand (COD) and total organic carbon (TOC) were $1013 \mathrm{mg} \mathrm{L}^{-1}$ and $286 \mathrm{mg} \mathrm{L}^{-1}$, respectively. It was not possible to determine the biochemical oxygen demand (BOD) of slurry sample. In this sense, the biodegradability parameter for the slurry studied was Non-Determinable (ND), indicating that the organic matter of the slurry studied is recalcitrant. Recalcitrant humic substances of landfill leachate the present low polydispersity. These refractory acids play a detached role in carrying pollutants in the environment with regard to carrying toxic metals and pesticides. Finally, it was possible to verify that the humic acids' complexing capacity indicates that hydroxyl and carboxyl groups may exist in larger quantities than the nitrogen and sulfur groups. Further, the high content of metals may indicate that the waste was not properly separated.
\end{abstract}

Keywords: landfill leachate, leachate, physicochemical characterization, solid waste management, spectroscopic methods. 


\section{Caracterização do chorume proveniente do aterro controlado da cidade de Guaratinguetá - SP, Brasil}

\section{RESUMO}

O objetivo deste trabalho foi avaliar os atributos físico-químicos do lixiviado de aterro controlado na cidade de Guaratinguetá-SP por métodos espectrométricos e espectrofotométricos para avaliar a formação de compostos persistentes. Além dos métodos de caracterização orgânica, como FTIR, RMN (RMN ${ }^{1} \mathrm{H}, \mathrm{RMN}{ }^{13} \mathrm{C}$ e APT), CG-MS, distribuição de massa molar e análise elementar $(\mathrm{CHN})$, os parâmetros proporcionados no Artigo 18 da CETESB e no artigo 34 do CONAMA 357/05. A estabilidade química e física foi verificada medida que foi sendo feita a caracterização analítica. A concentração de nitrogênio amoniacal é 20 vezes maior que a fornecida (20 mg L-1). Os Ba e Ni apresentaram concentrações acima das permitidas pela legislação (Artigo 18 da CETESB e Artigo 34 da CONAMA 357/05). Os valores de demanda química de oxigênio (DQO) e carbono orgânico total (TOC) foram de 1013 $\mathrm{mg} \mathrm{L}^{-1}$ e $286 \mathrm{mg} \mathrm{L}^{-1}$, respectivamente. A demanda bioquímica de oxigênio não foi determinada. Não foi possível determinar a demanda bioquímica de oxigênio (DBO), indicando que a matéria orgânica da pasta estudada é recalcitrante. Substâncias húmicas recalcitrantes de aterros lixiviam a baixa polidispersidade presente. Estes ácidos refractários desempenham um papel destacado no transporte de poluentes no ambiente para ser capaz de transportar metais tóxicos e pesticidas. Por fim, foi possível verificar a capacidade de complexação de ácidos húmicos que indica que os grupos hidroxila e carboxila podem existir em maiores quantidades do que os grupos nitrogênio e enxofre. Além disso, o alto teor de metais pode indicar que os resíduos não foram adequadamente separados.

Palavras-chave: caracterização físico-química, chorume, gerenciamento de resíduo sólido, lixiviado de aterro, métodos espectroscópicos.

\section{INTRODUCTION}

Solid wastes are defined by standard NBR 10.004:2004 (ABNT, 2004) as wastes in the solid and semi-solid state resulting from industrial, domestic, hospital, commercial, agricultural, services and sweeping activities (Silva et al., 2016; 2017). Their physical, chemical and biological characteristics vary according to their source or generating activity (Klein et al., 2017; Zhang et al., 2017a). Economic, social, geographic, educational, cultural, technological and legal factors affect the solid-waste-generation process concerning the qualitative and quantitative attributes (Li et al., 2017; Peng, 2017). Once generated, the waste may have its characteristics altered due to the management employed, which may result in waste with great harmful potential to public health and to the environment (Mandal et al., 2017; Silva et al., 2016; 2017; Li et al., 2017).

The formerly controlled landfill in the city of Guaratinguetá, in the State of São Paulo, in the Paraíba Valley region, worked as a garbage disposal site for 30 years, being deactivated in 2006. The controlled landfill had a total area of $30,000 \mathrm{~m}^{2}$, located on Estrada Américo Ranieri, in the Santa Luzia Neighborhood. For many years, the landfill's major characteristics were stench, fly and insect proliferation, and a large number of garbage diggers with varying age ranges. According to information from the Secretariat of Urban Services of Guaratinguetá (Municipal Administration 2004/2007), the municipality landfill received about 60 tons of garbage a day, produced by around 110,000 inhabitants. This controlled landfill was used to dispose of solid urban waste (SUW) which was compacted after being deposited in the site. The 
place is currently an Ecological Park, an initiative by the Guaratinguetá Autonomous Water and Sewage Services (SAAEG Municipal Company).

Although the controlled landfill has been deactivated, the slurry and wastewater keep being generated once the landfill keeps presenting decomposition reactions of the organic parcel until the wastes disposed of have been fully stabilized (Klein et al., 2017; Mandal et al., 2017; Van Turnhout, 2018). However, the liquid waste generated will be a polluting source of underground waters of the whole region circumscribed for a number of years, owing to the toxic character of the slurry gradually liberated with the decomposition of the organic matter and of the inorganic load leaching, since the effluent is not adequately collected by means of blanket and lateral ducts (Peng, 2017; Zhang et al, 2017a; 2017b). This occurs because this landfill does not meet some design requirements listed in the National Policy for Solid Wastes (Brazil) (Silva et al., 2016; 2017). It is therefore necessary to permanently characterize the physical-chemical parameters of the leachate material from the controlled landfill as a way of monitoring the landfill activity, and to propose solutions to possible remediation (Gomes et al., 2016; Peng, 2017; Mandal et al., 2017; Mohammad-Pajooh et al., 2017).

Nuclear Magnetic Resonance (NMR) is able to provide chemical structure information of whole organic matter, allowing the investigation of humus-containing samples without extraction and fractionation. Resonance regions can be assigned to lignin aromatic, alkyl, Osubstituted alkyl, carboxyl- and carbonyl-C (Lü et al., 2018). The principle means to explain FTIR spectra is by identifying the bands relating to humus generation (e.g. unsaturated $\mathrm{C}=\mathrm{C}$, aromatic $\mathrm{C}=\mathrm{C}$ ) and organic matter degradation (e.g., aliphatic, hydroxyl phenols, carboxylic acids, $\mathrm{N}-\mathrm{H}$ stretching, peptidic, $\mathrm{C}=\mathrm{O}$ of carboxylic acids, ketones, and aldehydes, $\mathrm{COO}$ of carboxylic acids, polysaccharides, alcohols, amines, amide, alkenes, ethers, esters). Despite the amount of FTIR, and NMR data discussed in the literature, the mechanism of humification of municipal waste is not yet completely understood (Lü et al., 2018). Lenz et al. (2016) studied six different abandoned Austrian municipal landfills wherein different sections were sampled quarterly over a period of 15 months. Several functional groups were assigned such as primary amides, aliphatic methylene, thiole, aromatic ring modes, amines, aromatic compounds, carboxylic acids, carboxyl groups, etc. Xiaoli et al. (2013) studied elemental analysis, Fourier transform infrared spectroscopy (FTIR), and Carbon-13 Cross-Polarization Magic-AngleSpinning Nuclear Magnetic Resonance $\left({ }^{13} \mathrm{C}\right.$ CP/MAS NMR) were carried out to characterize the chemical and structural properties of humic acids (HA) extracted from the leachate of both semi-aerobic and anaerobic full-scale landfills. According to the study of Xiaoli et al. (2013), when the FTIR spectra of HA from the semi-aerobic and anaerobic landfills were compared, appreciable differences in resolution and strength of assigned peaks were found. The FTIR spectra for the semi-aerobic landfill HA displayed relatively higher adsorption intensity at $1560 \mathrm{~cm}^{-1}$ than the anaerobic HA, which suggested that it may have more aromatic ring or $\mathrm{NH}$ structures. By comparison, the relative adsorption intensity at $1120 \mathrm{~cm}^{-1}$ and $1046 \mathrm{~cm}^{-1}$ of the anaerobic landfill was stronger than that of the HA from the semi-aerobic landfill, which indicated that the anaerobic landfill HA contained more stabilized components, such as polysaccharides or polysaccharide-like substances. The FTIR spectra of peaks at $1560-1575 \mathrm{~cm}^{-1}$ and $1640-50 \mathrm{~cm}^{-1}$, which, associated with aromatic $\mathrm{C}=\mathrm{C}$, strongly increased with the extension of the stabilization process. The peaks eventually merged to become one adsorption band at 1601-1645 $\mathrm{cm}^{-1}$. This finding suggested that the aromatic group content in HA rose significantly over time. The FTIR spectra of intensive peaks at $1400 \mathrm{~cm}^{-1}$ relates to for the aliphatic group content in HA. It decreased as stabilization proceeded and ultimately disappeared, which indicates that the aliphatic group component decreased over time.

Gel Permeation Chromatography (GPC) and Elemental CHN analysis are able to complement the characterization information from NMR and FTIR. Xiao et al. (2013) investigated degradation of landfill leachate after its characterization (sanitary landfill from 
Beijing, China). The chromatogram of raw leachate had a molecular weight (MW) distribution of $\mathrm{UV}_{254}$ active components with a retention time between 11-15 min. According to the separation mechanism of GPC, higher MW compounds were eluted earlier. The raw leachate consisted of higher MW compounds ranging from 300 to $2000 \mathrm{Da}$. Morozesk et al. (2017)

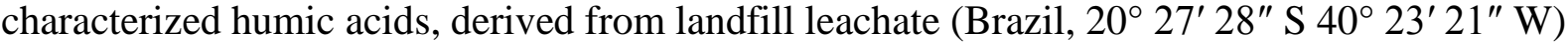
by elemental analysis. The authors found $\mathrm{C}$ content of $398.47 \mathrm{~g} \mathrm{~kg}^{-1}, \mathrm{H}$ of $70.60 \mathrm{~g} \mathrm{~kg}^{-1}, \mathrm{~N}$ of $59.78 \mathrm{~g} \mathrm{~kg}^{-1}$, and $\mathrm{O}$ of $471.15 \mathrm{~g} \mathrm{~kg}^{-1}$. The $\mathrm{C} / \mathrm{N}$ ratio of 56.50 in landfill $\mathrm{HA}$ was due to high nitrogen levels in these compounds, evidencing their potential as an important nitrogenous source.

In this sense, we here assessed the physical-chemical and microbiological attributes of the leachate of the controlled landfill in the city of Guaratinguetá-SP by spectrometric and spectrophotometric methods, according to the parameters provided in CETESB Article 18 (São Paulo, 1976) and CONAMA 357/05 Article 34 (CONAMA, 2005), and also emplyed organic characterization methods, such as FTIR, NMR $\left({ }^{1} \mathrm{H}-\mathrm{NMR},{ }^{13} \mathrm{C}-\mathrm{NMR}\right.$ and APT), GC-MS, molar mass distribution and elemental analysis (CHN); concurrently, chemical and physical stability was verified over time as a way of assessing the formation of compounds and complexes more refractory to those at the moment of sampling.

\section{MATERIALS AND METHODS}

\subsection{Sampling, reagents and solutions}

The landfill of the municipality of Guaratinguetá received about 60 tons of household waste per day, produced by about 110 thousand inhabitants. The leachate was collected in 2006 in channels arranged at the base of the municipal landfill $\left(22^{\circ} 48^{\prime} 16.7^{\prime \prime} \mathrm{S} 45^{\circ} 13^{\prime} 39.8^{\prime \prime} \mathrm{W}\right)$. Initially, the slurry "in natura" (untreated landfill slurry) was homogenized by manual stirring in a plastic barrel, to ensure the reproducibility of the analytical results, seeing that the sample has complex physical-chemical characteristics (elements in the colloidal form or associated to the matter in suspension). The slurry was collected from the controlled landfill of Guaratinguetá a single time and homogenized by mechanical stirring, finally being stored at $4^{\circ} \mathrm{C}$. The sampling was performed according to standard NBR 9898:1987 (ABNT, 1987).

All the chemical reagents were of the P.A. degree. The mineral acids used were of the Dinâmica brand. The metallic patterns used, with 1-mg mL $\mathrm{mL}^{-1}$ concentration, were of the SpecSol brand with NIST traceability, Reagent organic solvents and other chemical reagents of the Vetec brand.

The solutions were prepared by employing analytical degree reagents, ultrapure water obtained from using Milli-Q (Millipore Corp, de Billerica, MA, EUA) water system at $18.2 \mathrm{M} \Omega \mathrm{cm}$ resistivity, nitric and chloridric acid distilled in quartz sub-boiling (Milestone, Sorisole, Italy). To prevent contamination, the vials, glassware and polypropylene materials were washed and soaked in $10 \% \mathrm{v} \mathrm{v}^{-1} \mathrm{HNO}_{3}$ and fully washed with deionized water.

\subsection{Instrumentation}

All the analytical determinations of the metallic elements of interest in the samples "in natura" were performed in an atomic absorption spectrometer (graphite flame and oven), using an Aanalyst 800 Model by PerkinElmer. The equipment presents a double-beam optical system (single beam for graphite oven operation); motorized monochrome of the Littrow type for automatically selecting wavelength, adjustment and alignment; work range from 185 to $870 \mathrm{~nm}$, with 1800-line/mm diffraction grating and solid-state detector; background correction for flame, for deuterium lamp. The graphite oven has transversal heating, providing an even temperature profile, with background correction by longitudinal Zeeman effect. 
Multi-elemental characterization constitutes of element determination at trace level $\left(\mu \mathrm{g} \mathrm{L}^{-1}\right)(\mathrm{Ag}, \mathrm{As}, \mathrm{Cd}, \mathrm{Cr}, \mathrm{Hg}, \mathrm{Pb}$ and $\mathrm{Se})$ and macroelements $\left(\mathrm{mg} \mathrm{L}^{-1}\right)(\mathrm{B}, \mathrm{Ba}, \mathrm{Cu}, \mathrm{Sn}, \mathrm{Fe}, \mathrm{Mn}$, $\mathrm{Ni}$ and $\mathrm{Zn}$ ). The trace elements, macroelements and $\mathrm{Hg}$ were determined by employing GFAAS, FAAS and CVAAS, respectively.

\subsubsection{Sample preparation for multi-element determination by AAS}

To reduce the interference caused by the organic matter, and to convert metals associated to particles in a form capable of being atomized and characterized by atomic absorption spectrometry (AAS), the recommendation is to conduct an acid-digestion stage of the effluent (slurry) (APHA et al., 2012). Thus, the slurry acid digestion was carried out in closed system with reflow for later determining the elements of interest based on a procedure proposed by (Bianchi et al., 2012).

The metallic and semi-metallic elements determined in the slurry are provided by the CETESB Article 18 (São Paulo, 1976) and by CONAMA 430 (CONAMA, 2011), specifically dealing with characteristics of effluents to be discarded in receiving sources. The analytical characterization of the metals was performed by the atomic absorption spectrometry technique, with flame atomization and by graphite oven, according to the metal concentration in the sample. To assess the repeatability and reproducibility of the sample preparations by acid digestion, the analytical determination of the metallic elements was based on studies reporting the use of addition and recovery tests and the use of certified reference material for quantification by spectrometric techniques used for environmental samples (Salazar et al., 2011a; Bianchi et al., 2012; Gomes et al., 2016).

\subsection{Analysis of Chemical Oxygen Demand (COD)}

Due to the complex characteristics of the samples, adjustments of 5220 methodology $D$. Closed Reflux, Colorimetric Method from APHA Standard Methods were necessary to increase the reliability of analytical results (Peixoto et al., 2008; Salazar et al., 2011b).

In this procedure, the sample was heated for 2 hours with a strong oxidizing agent, potassium dichromate, in a closed system. The oxidation of organic compounds result from reducing the dichromate ion to green chromic ion. The COD reagent also contains silver and mercury ions. Silver is a catalyst, and mercury is used to control chloride interferences. To determine the accuracy of the method, a standard solution of $850 \mathrm{mg} \mathrm{L}^{-1}$ potassium biphthalate was used as the sample, which should present a result of $1,060 \mathrm{mg} \mathrm{L}^{-1} \mathrm{O}^{2}$ (Peixoto et al., 2008).

\subsection{Analysis of Total Organic Carbon (TOC) of the dissolved fraction}

The samples were filtered in $0.45 \mu \mathrm{m}$ filter and injected in the equipment with a high temperature oven $\left(680^{\circ} \mathrm{C}\right)$, containing platinum catalyst under an oxygen atmosphere. The $\mathrm{CO}_{2}$ generated is analyzed by non-dispersive infrared (NDIR). For determining TOC, Shimadzu equipment was used, Model TOC 5000A.

\subsection{Physical-chemical characterization of the slurry}

The physical-chemical characterization of the slurry consisted in analyzing the following parameters: multi-elemental analysis (Ag, As, B, Ba, Cd, Co, Cr-total, $\mathrm{Fe}, \mathrm{Fe}^{+2}, \mathrm{~F}^{-1}, \mathrm{Hg}, \mathrm{Mn}$, $\mathrm{Ni}, \mathrm{Pb}, \mathrm{Se}, \mathrm{Sn}$ and $\mathrm{Zn})$, cyanide $\left(\mathrm{CN}^{-1}\right)$, phenol, odor, oils and (mineral) greases, oils and greases, $\mathrm{pH}\left(25^{\circ} \mathrm{C}\right), \mathrm{S}^{-2}$, sedimentable and surfactant solids. The procedures for the physicalchemical characterizations were extracted from Standard Methods for Examination of Water and Wastewater (APHA et al., 2012), as presented in Table 1. 
Table 1. Methods and standards from Standard Methods for Examination of Water and Wastewater $22^{\text {nd }} E d$ (APHA et al., 2012) for characterizing the slurry samples.

\begin{tabular}{|c|c|}
\hline Physical and physical-chemical Parameters & Protocol or analytical method \\
\hline Arsenic (As) & 3114C. \\
\hline Total barium (total Ba) & 3111D. \\
\hline Boron (B) & 4500-B C. \\
\hline Total Cadmium (total Cd) & 3111B. \\
\hline Total lead (total Pb) & 3111B. \\
\hline Total cyanide (total CN) & $4500 \mathrm{CN} F$. \\
\hline Total copper (total $\mathrm{Cu})$ & 3111B. \\
\hline Total chromium (total $\mathrm{Cr}$ ) & 3111D. \\
\hline Biochemical oxygen demand (BOD) & 5210 B and Lima et al. (2006) \\
\hline Tin $(\mathrm{Sn})$ & 3111D. \\
\hline Total phenols & 5530D. (Direct) \\
\hline Total iron (total Fe) & 3111B. \\
\hline Fluoride $\left(\mathrm{F}^{-1}\right)$ & 4500F. D \\
\hline Ferrous ion $\left(\mathrm{Fe}^{+2}\right)$ & $3500-\mathrm{Fe} \mathrm{B}$ \\
\hline Manganese (Mn) & 3111B. \\
\hline Mercury (Hg) & 3112B. \\
\hline Total nickel (total Ni) & 3111B. \\
\hline Nitrogen total $\left(\mathrm{mg} \mathrm{L}^{-1}\right)$ & $4500 \mathrm{~N}$ org $\mathrm{B}$ and $4500 \mathrm{NH}_{3} \mathrm{~B}$ \\
\hline Oils and greases & 5520D. \\
\hline $\mathrm{pH}$ a $25^{\circ} \mathrm{C}$ & NBR 9251:1986 (ABNT, 1986) \\
\hline Silver (Ag) & 3111B. \\
\hline Selenium (Se) & 3114C. \\
\hline Sedimentable solids & $2540 \mathrm{~F}$. \\
\hline Sulfide $\left(\mathrm{S}^{-2}\right)$ & 4500- $S^{2} D$ \\
\hline Surfactants & $5540 \mathrm{C}$ \\
\hline Temperature $\left({ }^{\circ} \mathrm{C}\right)$ & APHA et al. (2012) \\
\hline Total zinc (total Zn) & $3111 \mathrm{~B}$ \\
\hline
\end{tabular}

\subsection{Organic spectroscopy characterization}

\subsubsection{Sample pre-treatment: extraction in organic solvent}

First, $100.00 \mathrm{~mL}$ of leachate "in natura" were acidified up to $\mathrm{pH} 1$, employing $\mathrm{HCl}$ concentration. Next, the slurry was placed in a 500-mL separatory funnel. The organic matter extraction procedure was carried out by using $3100.00-\mathrm{mL}$ aliquots of the n-hexane solvent. After extraction for a period of $5 \mathrm{~min}$ each, the 3 solvent fractions were combined and the aqueous residue was removed with anhydrous $\mathrm{Na}_{2} \mathrm{SO}_{4}$. The organic phase was finally transferred to a 500-mL round-bottomed flask. After the extraction procedure stage, the organic solvent was evaporated in a rotary evaporator (vacuum system and $50^{\circ} \mathrm{C}$ bath temperature). The same former extraction procedure was also performed by using dichloromethane and ethyl acetate solvents. The residual matter was used for organic characterization by employing the following analytical techniques: infrared (FTIR), nuclear magnetic resonance (protons, carbon 13 and APT - Attached Proton Test) and CHN (carbon, hydrogen and nitrogen elemental analysis).

\subsubsection{Nuclear magnetic resonance (NMR) analysis of protons, of carbon-13 and APT}

NMR analyses of proton $\left(\mathrm{NMR}{ }^{1} \mathrm{H}\right)$, carbon $13\left(\mathrm{NMR}{ }^{13} \mathrm{C}\right)$ and APT were performed in VARIAN equipment, Mercury Model. The sample (extraction residue) was dissolved in $0.6 \mathrm{~mL}$ of deuterated chloroform - CDCl3 (99.98\%) containing tetramethylsilane (TMS). The NMR 
${ }^{1} \mathrm{H}$ analysis was performed at a $300 \mathrm{MHz}$ frequency, with 32 accumulations $(\mathrm{nt}=32)$. Analysis by carbon resonance - NMR ${ }^{13} \mathrm{C}$ and $\mathrm{APT}$ - was performed at a $75-\mathrm{MHz}$ frequency.

\subsubsection{Analysis in the infrared region (FTIR)}

The sample dissolved in volatile organic solvent (chloroform) was dispersed in a tablet of sodium chloride $(\mathrm{NaCl})$, forming a film after the solvent evaporation. Spectra in the infrared region were obtained by Fourier transform (FTIR), from 4000 to $400 \mathrm{~cm}^{-1}$, using Perkin-Elmer equipment, Spectrum One model.

\subsubsection{Elemental analysis $(\mathrm{CHN})$}

The analyses of the carbon, hydrogen and nitrogen elements present in the extraction residue $(5.0 \mathrm{mg}$ ), were performed by the equipment Perkin-Elmer CHN 2400. The combustion process occurred at $925^{\circ} \mathrm{C}$, using oxygen with $99.995 \%$ purity.

\subsubsection{Analysis of molar mass distribution (GPC)}

The molar mass distribution of the slurry was determined from the dissolved organic fraction, using the gel permeation chromatography technique. The slurry, previously homogenized, was filtered in $0.45 \mu \mathrm{m}$ filter, and a $1.00 \mathrm{~mL}$ aliquot was diluted in a $10.0 \mathrm{~mL}$ volumetric flask with the eluent ( $\mathrm{Na} 2 \mathrm{HPO} 4.7 \mathrm{H} 2 \mathrm{O}$ at $50 \mathrm{mmol} \mathrm{L}-1+\mathrm{NaCl} 0.15 \mathrm{~mol} \mathrm{~L}-1$, in $\mathrm{pH}$ 12). The sample was then injected in the gel permeation chromatography instrument (GPC), keeping the mobile phase at a constant $0.7 \mathrm{~mL}$ min- 1 flow. The absorbance measurements were made in three wavelength values: 210, 254 and $280 \mathrm{~nm}$. GE equipment, Model ÄKTA 10 Purifier, was used with a Superose 12 column, 10/300 GL. The calibration curve was made with standard Blue Dextran (2000 kDa), albumin (66 kDa), carbonic anhydrase (29 kDa), cytochrome C (12.4 kDa), aprotinin $(6.5 \mathrm{kDa})$ and acetone $(58 \mathrm{Da})$, obtaining $\mathrm{R} 2=0.998$.

\section{RESULTS AND DISCUSSION}

\subsection{Physicochemical characterization of the untreated landfill slurry}

The physical, chemical and biological characteristics of the leachates depend on the type of waste, on the degree of decomposition, climate, season of the year, landfill age, depth of waste, type of landfill operation, among other things. It can thus be stated that the composition of leachates may considerably vary from one place to another, as well as in the same site and with the seasons of the year (MOHAMMAD-PAJOOH et al., 2017). It is therefore necessary to obtain the largest amount of information about a particular leachate under study, correlating its physical and chemical characteristics with the treatment processes involved. Among the major parameters used for characterizing leachate liquids are total organic carbon (TOC), biochemical oxygen demand (BOD), chemical oxygen demand (COD), $\mathrm{pH}$, nitrogen and ammoniacal total, solid series, and heavy metals, among other things. Table 2 shows the physical and chemical characterization of the slurry "in natura" of the former controlled landfill of the city of Guaratinguetá-SP, according to the CETESB Article 18 (São Paulo, 1976) and CONAMA 430 (CONAMA, 2011) parameters. 
Table 2. Inorganic analytical parameters of the slurry "in natura", according to the conditions and effluent discharge standards (CONAMA, 2011; São Paulo, 1976). Results of spectrometry analytical validation of atomic and spectrophotometry UV-Vi absorption.

\begin{tabular}{|c|c|c|c|c|c|c|c|c|}
\hline Parameters & Average & Minimum & Maximum & $\mathrm{Sp}$ & Spike & Rec. $(\%)$ & $\mathrm{N}$ & $\begin{array}{l}\text { Maximum content } \\
\text { allowed }\left(\mathrm{mg} \mathrm{L}^{-1}\right)\end{array}$ \\
\hline As $\left(\mu \mathrm{g} \mathrm{L}^{-1}\right)$ & $<10.0$ & $<10.0$ & $<10.0$ & - & 50.0 & 95.0 & 2 & 0.5 \\
\hline $\mathrm{Ba}\left(\mathrm{mg} \mathrm{L}^{-1}\right)$ & 6.68 & 4.88 & 8.48 & 2.55 & 10.0 & 96.0 & 2 & 5.0 \\
\hline $\mathrm{B}\left(\mathrm{mg} \mathrm{L}^{-1}\right)$ & 0.03 & 0.03 & 0.03 & 0.01 & 5.0 & 93.0 & 2 & 5.0 \\
\hline $\mathrm{Cd}\left(\mu \mathrm{g} \mathrm{L}^{-1}\right)$ & 6.26 & 4.03 & 11.71 & 3.66 & 14.87 & 119.9 & 4 & 0.2 \\
\hline $\mathrm{Pb}\left(\mu \mathrm{g} \mathrm{L}^{-1}\right)$ & 9.51 & 7.51 & 12.82 & 2.89 & 10.20 & 107.5 & 3 & 0.5 \\
\hline $\mathrm{CN}^{-1}\left(\mathrm{mg} \mathrm{L}^{-1}\right)$ & - & - & - & - & - & - & - & 0.2 \\
\hline $\mathrm{Cu}\left(\mathrm{mg} \mathrm{L}^{-1}\right)$ & 0.14 & 0.08 & 0.21 & 0.05 & 0.49 & 96.0 & 7 & 1.0 \\
\hline $\mathrm{Cr}\left(\mu \mathrm{g} \mathrm{L}^{-1}\right)$ & 85.73 & 78.00 & 93.46 & 10.93 & & 95.0 & 1 & 0.5 \\
\hline $\operatorname{Sn}\left(\mathrm{mg} \mathrm{L}^{-1}\right)$ & $<1.0$ & $<1.0$ & $<1.0$ & - & 5.0 & 94.0 & 2 & 4.0 \\
\hline $\mathrm{Fe}\left(\mathrm{mg} \mathrm{L}^{-1}\right)$ & 6.84 & 3.71 & 10.88 & 2.38 & 20.73 & 102.0 & 7 & - \\
\hline $\mathrm{Fe}^{2+}\left(\mathrm{mg} \mathrm{L}^{-1}\right)$ & 1.09 & 0.98 & 1.21 & 0.10 & 4.84 & 101.0 & 6 & 15.0 \\
\hline Fluoride $\left(\mathrm{mg} \mathrm{L}^{-1}\right)$ & 0.17 & 0.17 & 0.17 & 0.01 & 2.0 & 99.0 & & 10.0 \\
\hline $\operatorname{Mn}\left(\mathrm{mg} \mathrm{L}^{-1}\right)$ & 0.42 & 0.36 & 0.54 & 0.06 & 0.54 & 103.6 & 7 & 1.0 \\
\hline $\mathrm{Hg}\left(\mu \mathrm{g} \mathrm{L}^{-1}\right)$ & $<11.0$ & $<11.0$ & $<11.0$ & - & 50.0 & 95.0 & 2 & 0.01 \\
\hline $\mathrm{Ni}\left(\mathrm{mg} \mathrm{L}^{-1}\right)$ & 4.03 & 2.72 & 5.06 & 0.84 & 4.30 & 101.7 & 5 & 2.0 \\
\hline $\mathrm{N}-\mathrm{NH}_{3}\left(\mathrm{mg} \mathrm{L}^{-1}\right)$ & 398.02 & 273.31 & 544.04 & 121.45 & 5.0 & 93.0 & 8 & 20.0 \\
\hline $\mathrm{N}-\mathrm{Org}\left(\mathrm{mg} \mathrm{L}^{-1}\right)$ & 28.80 & 2.50 & 49.57 & 21.64 & 5.0 & 90.0 & 4 & - \\
\hline $\operatorname{Ag}\left(\mu \mathrm{g} \mathrm{L}^{-1}\right)$ & 68.22 & 4.67 & 110.00 & 55.94 & 50.0 & 97.1 & 3 & 0.1 \\
\hline $\mathrm{Se}$ & - & - & - & - & - & - & - & 0.3 \\
\hline $\mathrm{S}^{2-}\left(\mu \mathrm{g} \mathrm{L}^{-1}\right)$ & $<0.002$ & $<0.002$ & $<0.002$ & - & $5.0 \times 10^{3}$ & 95.7 & 2 & 1.0 \\
\hline $\mathrm{Zn}\left(\mathrm{mg} \mathrm{L}^{-1}\right)$ & 0.45 & 0.04 & 1.10 & 0.34 & 2.07 & 102.2 & 8 & 5.0 \\
\hline Sol. Hexane $\left(\mathrm{mg} \mathrm{L}^{-1}\right)$ & $<5.0$ & $<5.0$ & $<5.0$ & - & 48.83 & 132.70 & 2 & 100.0 \\
\hline Phenols $\left(\mathrm{mg} \mathrm{L}^{-1}\right)$ & 0.42 & 0.41 & 0.42 & 0.01 & 5.0 & 97.3 & 2 & 0.5 \\
\hline Phosphorus (mg L ${ }^{-1}$ ) & 8.69 & 8.69 & 8.69 & 0.01 & 10.0 & 95.0 & 2 & - \\
\hline $\mathrm{pH}$ & 8.05 & 7.90 & 8.20 & 0.21 & - & - & 2 & 5.00 to 9.00 \\
\hline Conductivity $\left(\mathrm{mS} \mathrm{cm}^{-1}\right)$ & 7.074 & 6.683 & 7.464 & 0.552 & - & - & 2 & - \\
\hline $\mathrm{COD}\left(\mathrm{mg} \mathrm{L}^{-1}\right)$ & 1013 & 939 & 1105 & 51 & - & - & 12 & - \\
\hline $\mathrm{BOD}\left(\mathrm{mg} \mathrm{L}^{-1}\right)$ & ND & ND & ND & - & - & - & 6 & - \\
\hline TOC $\left(\mathrm{mg} \mathrm{L}^{-1}\right)$ & 286 & 267 & 317 & 27 & - & - & 3 & - \\
\hline Total Fixed Solids (TFS) & 3.669 .50 & 3.653 .00 & 3.686 .00 & 23.33 & - & - & 2 & - \\
\hline Total Volatile Solids (TVS) & 1.032 .50 & 1.008 .00 & 1.057 .00 & 34.65 & - & - & 2 & - \\
\hline Fixed Suspended Solids (FSS) & 22.33 & 10.00 & 37.00 & 13.65 & - & - & 3 & - \\
\hline Volatile Suspended Solids (VSS) & 13.17 & 4.50 & 25.00 & 10.61 & - & - & 3 & - \\
\hline Total Suspended Solids (TSS) & 38.75 & 36.00 & 41.50 & 3.89 & - & - & 2 & - \\
\hline
\end{tabular}

(ND) Non-Determinable; Spike: known addition of analytical standard in pre-quantified sample; N: number of replicates.

Table 2 verifies that some slurry characterization parameters are above the concentrations allowed by the legislation in force (São Paulo, 1976; CONAMA, 2011). Barium presents a concentration 1.3 times as great as that permitted $\left(5.0 \mathrm{mg} \mathrm{L}^{-1}\right)$. Nickel has twice the concentration allowed $\left(2.0 \mathrm{mg} \mathrm{L}^{-1}\right)$. The ammoniacal nitrogen concentration is 20 times as great as that provided $\left(20 \mathrm{mg} \mathrm{L}^{-1}\right)$. The addition and analyte recovery tests verify a minimum $90 \%$ recovery in all the analytical methodologies used, which therefore ensures the reliability of the spectrometric and spectrophotometric analytical results presented in Table 2. For being predominantly anaerobic environments, sanitary landfills produce effluents with considerably low nitrite and nitrate concentrations (Klein et al., 2017; Mandal et al., 2017; Van Turnhout, 2018). Conversely, the great biological activity found both in the waste mass and in the drainage system causes most of the organic nitrogen to be converted into ammoniacal nitrogen within the very landfill. Hence, there are great concentrations of ammonia and very little organic nitrogen in the leachate, which is evidenced in Table 2.

As stated by (Zhang et al., 2017b), ammonia is an important indicator of leachate contamination in water bodies. Most of the ammonia found in the leachate derives from organic 
matter degradation. The major nitrogenous organic compounds which act as a source of ammonia are proteins. Proteins are organic macromolecules formed by the combination of a large number of amino acids. In biological decomposition, proteins are first broken into their amino acids, which then undergo deamination (removal of the amine group). Part of the ammonia produced is incorporated in the cell growth and its excess is released as ammonium ion $\left(\mathrm{NH}_{4}^{+}\right)$(Van Turnhout, 2018).

Even though phosphorous is not provided by CETESB Article 18 (São Paulo, 1976) or by CONAMA 357/05 article 34 (CONAMA, 2005), its concentration in the slurry is considerable, and its high contents significantly influence the eutrophication processes of aquatic biota. The main chemical element used to control eutrophication is phosphorous, since the cyanobacteria are capable of fixing atmospheric nitrogen, not allowing the reduction in nitrogen concentration with the reduction in affluent load (Von Sperling, 2005; Peng, 2017). Practically the whole of the phosphorus found in leachates is in the form of orthophosphates (Van Turnhout, 2018). They act as an alkaline cover, contributing to the partial alkalinity ( $\mathrm{pH}=8.05$, Table 2 ). Phosphates derive mainly from organic matter (Li et al., 2017).

Table 2 shows the low results for COD (1,013 $\left.\mathrm{mg} \mathrm{L}^{-1}\right)$, for BOD (ND) and for TOC (286 mg L $\mathrm{m}^{-1}$ ). The biodegradability parameter obtained for the slurry studied was NonDeterminable $(N D)$, indicating that the organic matter of the slurry studied is recalcitrant (Fan et al., 2007). $\mathrm{BOD}_{5} / \mathrm{COD}$ ratio values below 0.05 are characteristic of stabilized leachates, nontreatable by biological methods (Deng, 2007). The fraction of organic matter oxidizable by potassium dichromate, in the COD technique, was obtained by the TOC/COD ratio, with a 0.28 response (Li et al., 2017; Peng, 2017; Van Turnhout, 2018).

The BOD and COD concentrations tend to suffer reductions during the degradation of the landfill wastes over the years. However, BOD decreases faster in relation to COD, which remains in the leachate due to the organic matter, which is difficult to degrade. Theoretically, these stability stages of sanitary landfills can be divided in function of the BOD/COD ratio observed in the leachates; namely: $\mathrm{BOD} / \mathrm{COD}>0.5 \mathrm{mg} \mathrm{L}^{-1}$ indicates a new and unstable landfill; $0.1<\mathrm{BOD} / \mathrm{COD}<0.5$ indicates a moderately stable landfill; BOD/COD $<0.1$ indicates an old and stable landfill. All this information justifies the low COD $\left(1,013 \mathrm{mg} \mathrm{L}^{-1}\right)$ value and the negligible value of BOD $\left(<5.0 \mathrm{mg} \mathrm{L}^{-1}\right)$, once the former controlled landfill of Guaratinguetá - SP had been active for about 30 years, on the date the leachate studied was collected. Also verified were the concentrations of the total inorganic and organic solids, which, despite not considering specificity, the results help to analytically assess the untreated landfill slurry (Peng, 2017; Van Turnhout, 2018; Zhang et al., 2017b).

Table 2 includes the STF/STV ratio, which shows that the total inorganic fraction found in the leachate is 3.6 times as great as the total organic fraction. Part of the STF is indicated by the inorganic compounds shown in Table 2. The suspension matter, however, shows that the organic fraction, given by the SSV/SSF ratio, corresponds to about $59 \%$ of the total. Heavy metals do not originate in chemical reactions; they will only appear in the leachate if they have been introduced in the landfill. These metals are not necessarily a symptom that there are industrial wastes being illegally disposed of. Metals are present in all materials, including living beings. Domestic wastes, especially when not adequately separated at their origin, may be a significant source of metals. Moreover, another highly important metal source, especially iron, is the clayey soil used in cover layers and in waterproofing systems. The minerals found in the clay used in cover layers may be degraded by the carbonic acid found in rainwater, which derives from the atmosphere $\mathrm{CO}_{2}$. This process releases metals which infiltrate the landfill together with water, and may or not become a part of the leachate (Peng, 2017; Van Turnhout, 2018; Zhang et. al., 2017a).

During the organic matter stabilization process, the biodegradable fraction of the compounds discharged in the municipal landfill is consumed, being replaced with refractory 
organic compounds. It is therefore necessary to collect a larger amount of information about this class of compounds, which predominate in leachates, by means of different chemical characterization techniques, including FTIR and NMR (protons, carbon 13 and APT) spectroscopy analyses, besides the distribution of molecular mass and of elemental analysis.

Figure 1 shows the FTIR graph of the slurry "in natura" obtained after the liquid-liquid extraction procedure.

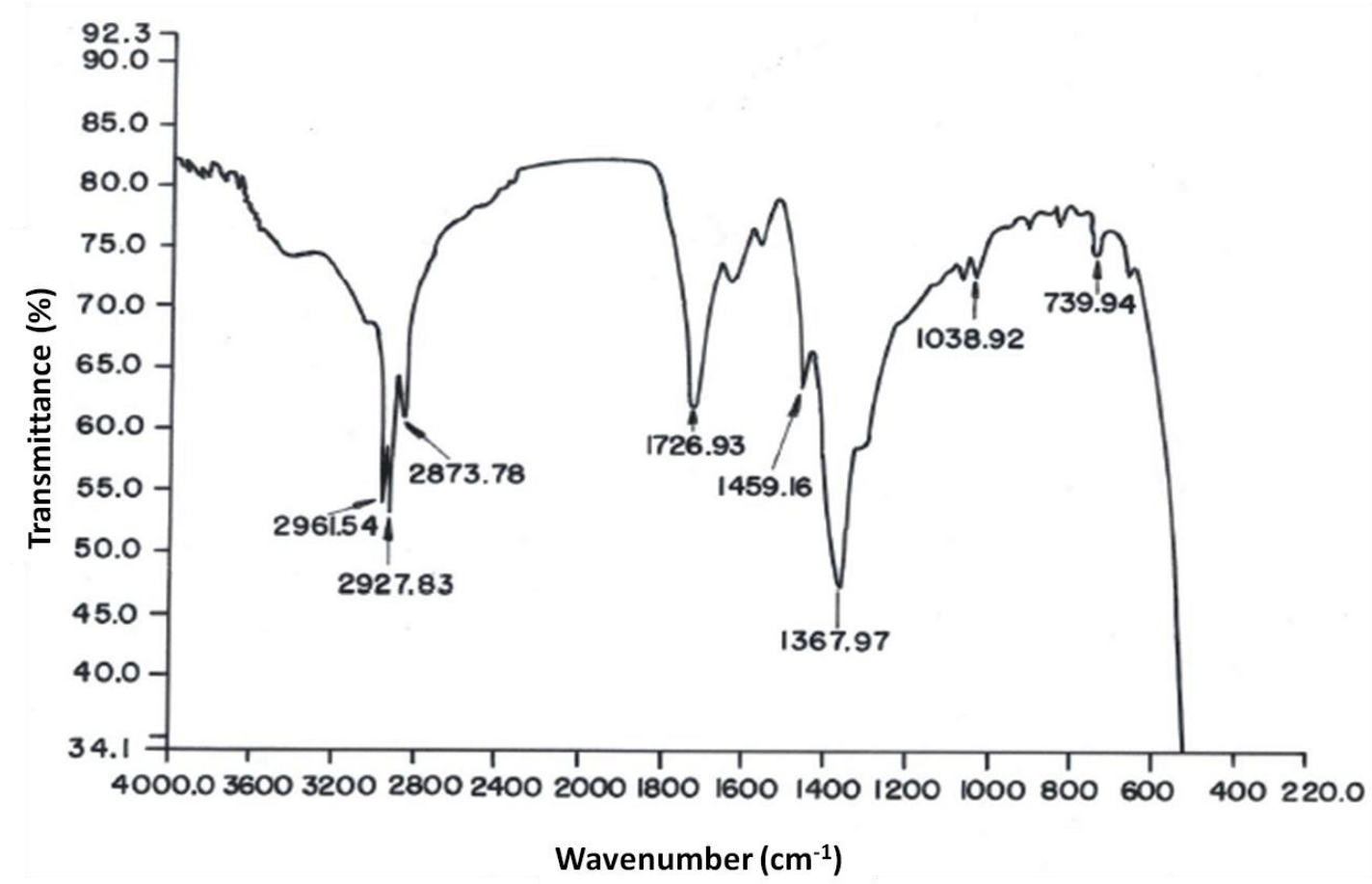

Figure 1. Infrared spectrum by Fourier transform (FTIR) of the slurry "in natura" residue obtained by extraction in ethyl acetate.

The spectrum in the infrared region by Fourier transform (FTIR) presented in Figure 1 is characterized by transmittance bands corresponding to the aromatic, aliphatic, carboxylic and hydroxyl groups (Christensen et al., 1998). A wide band is verified in the region between 2300 and $3600 \mathrm{~cm}^{-1}$, characteristic of organic acids, as expected in slurry, the main group of organic compounds of which are humic and fulvic acids, with a marked presence of carboxylic groups and of weak acid groups, such as the phenolic ones (Christensen et al., 1998). In $3419 \mathrm{~cm}^{-1}$, there is a characteristic band of hydroxyls. A $3047 \mathrm{~cm}^{-1}$ transmittance band is characteristic of aromatic rings in general, and may correspond, for example, to phenolic groups. 2961, 2927 and $2873 \mathrm{~cm}^{-1}$ bands correspond to carbon/hydrogen bonds of the $\mathrm{CH}, \mathrm{CH}_{2}$ and $\mathrm{CH}_{3}$ types of organic aliphatic chains. At $1726 \mathrm{~cm}^{-1}$, the carbonyl band $(\mathrm{C}=\mathrm{O})$ predominates and, at $1367 \mathrm{~cm}^{-1}, \mathrm{CH}_{3}$ groups bonded to carbonyl (Chai et al., 2007; Huo et al., 2008). The main mechanism for adsorbing pollutants (e.g. metals and pesticides) in organic matter dissolved in underground waters, including the class of humic acids, is ionic exchange involving the hydroxyl groups (3419 $\mathrm{cm}^{-1}$ transmittance band) and carbonyls from carboxylic acids $\left(1,726 \mathrm{~cm}^{-1}\right)$ (Dia et al., 2017; Van Turnhout et al, 2018).

The analyses by nuclear magnetic resonance provide basic structural information on the organic matter found in the leachate under study, confirming and complementing the data presented by the FTIR technique. By analyzing NMR ${ }^{1} \mathrm{H}$, relative quantitative mass information can be obtained, as opposed to the FTIR technique, which is essentially qualitative. Table 3 shows the results from the de NMR 1H and 13C analyses, and Figure 2 shows the ATP spectrum of the slurry "in natura". 
Table 3. Regions of chemical displacement of ${ }^{1} \mathrm{H}$ and the respective relative contributions of the organic compounds extracted from the slurry "in natura".

\begin{tabular}{|c|c|c|}
\hline $\begin{array}{l}\text { Regions } \delta(\mathrm{ppm}) \text { of } \\
\text { chemical displacement }\end{array}$ & Attribution & $\begin{array}{c}\text { Relative } \\
\text { contribution }(\%)\end{array}$ \\
\hline I $(0.4-1.7)$ & $\begin{array}{l}\text { Protons of terminal } \mathrm{CH}_{3} \text { and protons of } \mathrm{CH}_{2}, \mathrm{CH} \\
\text { from methylene chains, etc. }\end{array}$ & 72.3 \\
\hline II (1.7-3.3) & $\begin{array}{l}\text { Protons of } \mathrm{CH}_{3}, \mathrm{CH}_{2} \text { and } \mathrm{CH} \text { linked to aromatic } \\
\text { or carboxylic groups, etc. }\end{array}$ & 16.1 \\
\hline III (3.3-4.6) & $\begin{array}{l}\text { Protons of carbon } \alpha \text { linked to oxygen, } \\
\text { carbohydrates, etc. }\end{array}$ & 7.1 \\
\hline IV (6.5-8.1) & $\begin{array}{l}\text { Aromatic protons (including quinone, phenol, } \\
\text { etc.) }\end{array}$ & 4.5 \\
\hline
\end{tabular}

Characteristic peaks of aromatic protons were verified in the region between 8.1 and $7.5 \mathrm{ppm}$. The intense peak found in the $7.27 \mathrm{ppm}$ region corresponds to the deuterated chloroform solvent used in the analysis. Peaks between 4.6 and 3.3 correspond to carbon protons linked to oxygen (e.g. carbohydrates). Peaks from 1.7 to $0.4 \mathrm{ppm}$, are characteristic of $\mathrm{CH}_{3}, \mathrm{CH}_{2}$ and $\mathrm{CH}$ of aliphatic chains. In the proton spectrum, the different regions were quantified, according to (Kang et al., 2002).

Most of the protons analyzed (about $72 \%$ ) derive from $\mathrm{CH}_{3}, \mathrm{CH}_{2}$ and $\mathrm{CH}$ of aliphatic chains. Also found in large proportions $(\sim 16 \%)$ were $\mathrm{CH}_{3}, \mathrm{CH}_{2}$ and $\mathrm{CH}$ protons linked to aromatic groups and/or carboxylic groups. Carbon protons linked to oxygen $(\sim 7 \%)$ and aromatic protons $(4,5 \%)$ were found in small proportions.

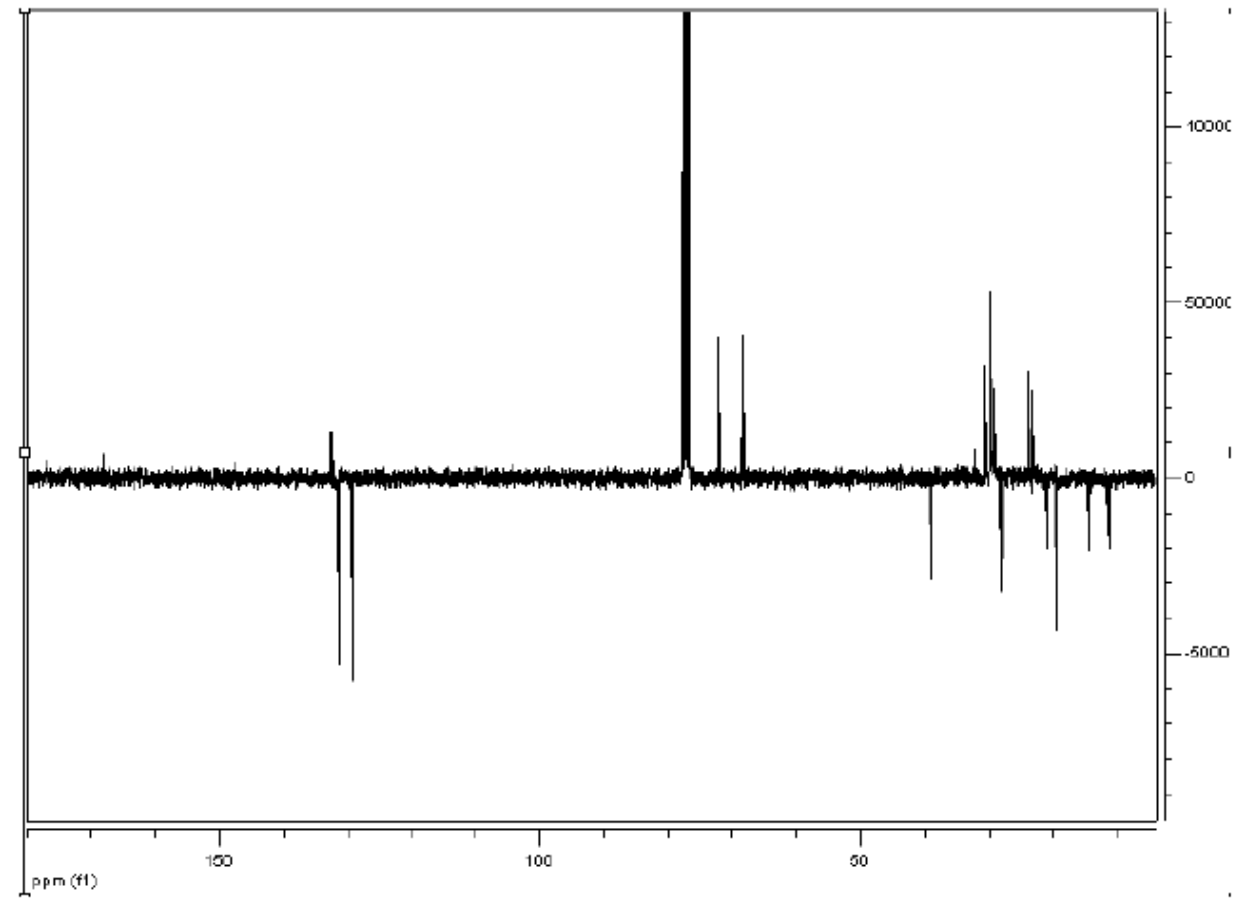

Figure 2. NMR ${ }^{13} \mathrm{C}$ spectrum of the extraction residue of the slurry "in natura".

$\mathrm{NMR}{ }^{13} \mathrm{C}$ analyses indicated intense and well-defined peaks in the region of the chemical displacement from 0 to $50 \mathrm{ppm}$, corresponding to aliphatic carbons. In a region comprehended between 50 and $70 \mathrm{ppm}$, characteristic peaks of methyl and methylene groups close to heteroatoms were found, such as $\mathrm{CH}_{3}$ of the acetyl group. Between 120 and $140 \mathrm{ppm}$, the presence of aromatic carbons was verified. Lastly, peaks between 160 and 180 ppm were 
verified, corresponding to carboxylic carbons, carbons in aldehyde, ketones and quaternary carbons. The data from NMR are coherent with the information obtained by the FTIR technique.

The determination of molar mass distribution in the slurry "in natura" was performed in 254 and $280 \mathrm{~nm}$ (Figures 3a and 3b, respectively).
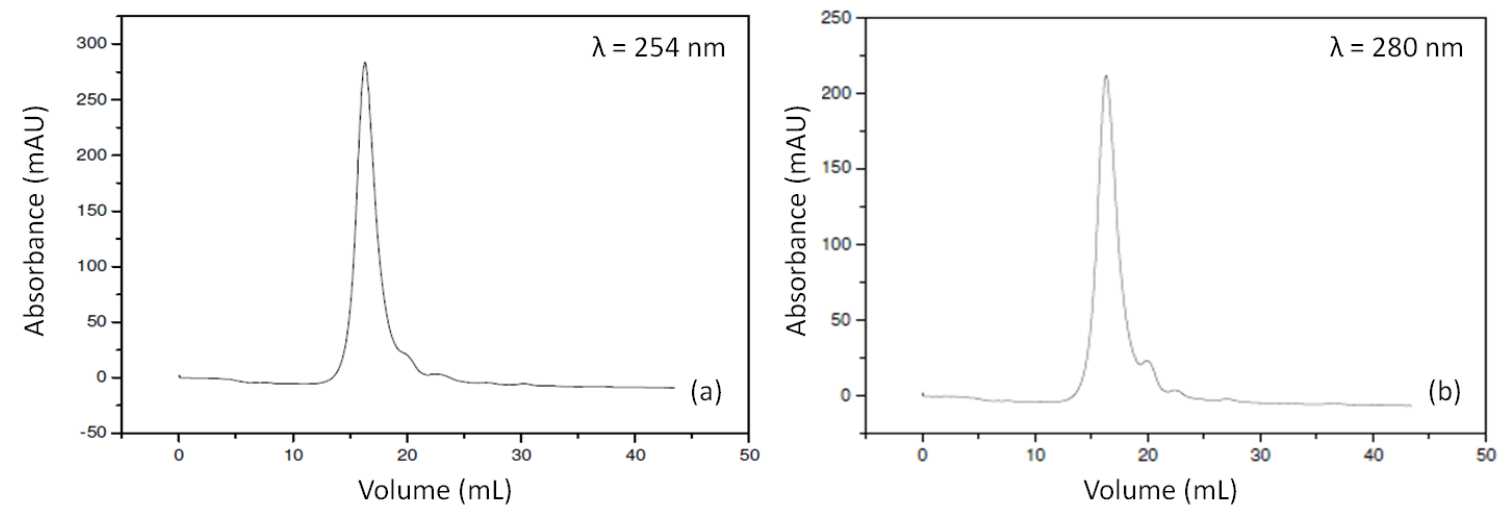

Figure 3. Chromatogram, at $254 \mathrm{~nm}$ (a) and at $280 \mathrm{~nm}$ (b), of the slurry "in natura" filtered at $45 \mu \mathrm{m}$ and diluted 10 times.

The analysis verified that the current effluent has a molar mass of $5.58 \mathrm{kDa}$, with 1.16 polydispersity. The soluble organic matter of the slurry collected from the controlled landfill of Guaratinguetá-SP is thus verified to be constituted by macromolecules with low polydispersity value, implying homogeneity of the carbonaceous matter molar mass. The low response from the $5.58 \mathrm{kDa}$ molar mass (1.16 polydispersity) of that landfill leachate (landfill of about 30 years of age) is coherent with the literature values for stabilized cell leachates (Christensen et al., 1998; Pereira et al., 2007; Dia et al., 2017).

\subsection{Elemental analysis ( $\mathrm{CHN})$ of the slurry "in natura"}

To complement the chemical characterization of the municipal landfill leachate, elemental analysis of the sample was performed. Elemental analysis of organic compound provides information on its chemical composition, and in a way, on its chemical structure. For a natural substance, the elemental analysis can often provide information on the origin of the material and on the conditions under which it was formed. Table 4 shows the elemental analysis, in duplicate (N), of the slurry "in natura" of the former controlled landfill of the city of Guaratinguetá-SP.

Table 4. Results of the elemental analysis $(\mathrm{CHN})$ of the slurry "in natura" of the former controlled landfill of the city of Guaratinguetá-SP.

\begin{tabular}{ccccc}
\hline Elements & Average & Minimum & Maximum & $\mathrm{N}$ \\
\hline $\mathrm{C}(\%)$ & 57.21 & 57.19 & 57.23 & 2 \\
$\mathrm{H}(\%)$ & 6.90 & 6.81 & 6.99 & 2 \\
$\mathrm{~N}(\%)$ & 1.89 & 1.78 & 2.00 & 2 \\
\hline
\end{tabular}

A high percentage mass content of carbon is verified, with a $57.21 \%$ response. The $\mathrm{C} / \mathrm{H}$ ratio of the slurry "in natura" is 8.29 and the $\mathrm{C} / \mathrm{N}$ ratio is 30.27 (Table 4). Fulvic acids have molecular mass between 200 and $2000 \mathrm{Da}$ and humic acids, over $2000 \mathrm{Da}$ (Huo et al., 2008; Zhang et al., 2017a). Fulvic acids tend to be more difficult to degrade than humic acids (McBean et al., 1995). Humic acids are materials formed by the aggregation of small molecules resulting from the incomplete (chemical and biological) degradation from vegetal and animal wastes, and from synthesizing microorganisms (Silva et al., 2017). There is still no consensus regarding the spatial structure of humic substances, but the humic acid is believed to be constituted of two 
main components: aromatic rings deriving from lignin and nitrogen from microorganism proteins (Dia et al., 2017). These rings are linked among them, be they condensed or not. The humic acids complexing capacity indicates that hydroxyl and carboxyl groups may exist in larger quantities than the nitrogen and sulfur groups. Carbon corresponds to $58 \%$ of the mass. This, added to the set of results presented for COD, BOD, FTIR, NMR, GPC and CHN, therefore indicates that the slurry of Guaratinguetá-SP is mainly constituted of humic acids, of difficult biodegradation, and able to form chelates with the metals present in aqueous medium (Table 2), solubilizing them even in basic medium ( $\mathrm{pH}=8.05$, Table 2).

These refractory acids play an important role by conveying pollutants to the environment by being able to form metallic chelates, for transporting pesticides in general and for being precursors of mutagenic products with supply-water chlorination (Wiszniowski et al., 2004). Humic substances have varied chemical composition. The variations in the degree of polymerization, in the number of lateral and radical chains that may be found in humic substances, account for there not being two identical humic molecules.

\section{CONCLUSIONS}

The leachate from the municipal landfill of Guaratinguetá (Sao Paulo, Brazil) is composed of a high content of salts, ammonia, and of recalcitrant humic substances. Ba and Ni with concentrations above those permitted by legislation is an indication that domestic wastes are not adequately separated in the households. Furthermore, the recalcitrant humic substances presented low polydispersity, with molecular mass characteristic of leachates from stabilized municipal landfills, with marked presence of aliphatic chains, aromatic rings in general, phenolic, and carboxylic groups. These refractory acids play a detached role in carrying pollutants in the environment by being able to carry toxic metals (forming metallic chelates even in basic medium) and pesticides in general; further, these substances are precursors of mutagenic products with the chlorination of supply water.

\section{REFERENCES}

AMERICAN PUBLIC HEALTH ASSOCIATION - APHA; AMERICAN WATER WORKS ASSOCIATION - AWWA; WATER ENVIRONMENT FEDERATION - WEF. Standard methods for examination of water and wastewater. 22nd. ed. Washington, DC, 2012.

ASSOCIAÇÃO BRASILEIRA DE NORMAS TÉCNICAS - ABNT. NBR 9251: Water Determination of $\mathrm{pH}$ - Electrometric method - Test method. 1 ed. Rio de Janeiro, 1986.

ASSOCIAÇÃO BRASILEIRA DE NORMAS TÉCNICAS - ABNT. NBR 9898: Preservation and sampling techniques of liquid effluents and receptor bodies - Procedure. 1 ed. Rio de Janeiro, 1987.

ASSOCIAÇÃO BRASILEIRA DE NORMAS TÉCNICAS - ABNT. NBR 10004: Solid waste - Classification. 1 ed. Rio de Janeiro, 2004.

BIANCHI, S. R. et al. Evaluation of a Collision-Reaction Interface (CRI) for Carbon Effect Correction on Chromium Determination in Environmental Samples by ICP-MS. $\begin{array}{lllllllll}\text { Analytical Letters, } & \text { v. } 45, \quad \text { n. } 18, & \text { p. 2845-2855, } 30 & \text { Nov. } 2012 .\end{array}$ https://doi.org/10.1080/00032719.2012.702176

CHAI, X. et al. Spectroscopic studies of the progress of humification processes in humic substances extracted from refuse in a landfill. Chemosphere, v. 69, n. 9, p. 1446-1453, Nov. 2007. https://doi.org/10.1016/j.chemosphere.2007.04.076 
CHRISTENSEN, J. B. et al. Characterization of the dissolved organic carbon in landfill leachate-polluted groundwater. Water Research, v. 32, n. 1, p. 125-135, 1998. https://doi.org/10.1016/S0043-1354(97)00202-9

CONSELHO NACIONAL DO MEIO AMBIENTE - CONAMA. Resolução nº 357/2005, de 17 de março de 2005. Diário Oficial [da] União, Brasília, n. 53, p. 58-63, 18 mar. 2005.

CONSELHO NACIONAL DO MEIO AMBIENTE - CONAMA. Resolução nº 430/2011, de 13 de maio de 2011. Diário Oficial [da] União, Brasília, n. 92, p. 89, 16 maio 2011.

DENG, Y. Physical and oxidative removal of organics during Fenton treatment of mature municipal landfill leachate. Journal of Hazardous Materials, v. 146, n. 1-2, p. 334340, 2007. https://doi.org/10.1016/j.jhazmat.2006.12.026

DIA, O. et al. Electrocoagulation of bio-filtrated landfill leachate: Fractionation of organic matter and influence of anode materials. Chemosphere, v. 168, p. 1136-1141, 2017. https://doi.org/10.1016/j.chemosphere.2016.10.092

FAN, H.-J. et al. Using FeGAC/H2O2 process for landfill leachate treatment. Chemosphere, v. 67, n. 8, p. 1647-1652, 2007. https://doi.org/10.1016/j.chemosphere.2006.09.075

GOMES, B. C. V. et al. Potencial toxicológico de metais presentes em solos de cemitérios de Santa Maria - RS. Revista Ambiente \& Agua, v. 11, n. 1, 2016. https://doi.org/10.4136/ambi-agua.1723

HUO, S. et al. Characteristics of dissolved organic matter (DOM) in leachate with different landfill ages. Journal of Environmental Sciences, v. 20, n. 4, p. 492-498, 2008. https://doi.org/10.1016/S1001-0742(08)62085-9

KANG, K.-H.; SHIN, H. S.; PARK, H. Characterization of humic substances present in landfill leachates with different landfill ages and its implications. Water Research, v. 36, n. 16, p. 4023-4032, 2002. https://doi.org/10.1016/S0043-1354(02)00114-8

KLEIN, K. et al. A pilot study of three-stage biological-chemical treatment of landfill leachate applying continuous ferric sludge reuse in Fenton-like process. Clean Technologies and Environmental Policy, v. 19, n. 2, p. 541-551, 2017. https://doi.org/10.1007/s10098016-1245-5

LENZ, S.; BÖHM, K.; OTTNER, R.; HUBER-HUMER, M. Determination of leachate compounds relevant for landfill aftercare using FT-IR spectroscopy. Waste Management, v. 55, p. 321-329, 2016. https://doi.org/10.1016/j.wasman.2016.02.034

LI, Y. L. et al. Simultaneous chemical oxygen demand removal, methane production and heavy metal precipitation in the biological treatment of landfill leachate using acid mine drainage as sulfate resource. Journal of Bioscience and Bioengineering, v. 124, n. 1, p. 71-75, 2017. https://doi.org/10.1016/j.jbiosc.2017.02.009

LIMA, L. S.; IZÁRIO FILHO, H. J.; CHAVES, F. J. M. Determinação da demanda bioquímica de oxigênio para teores $\leq 5$ mg L-1 O2. Revista Analítica, v. 25, n. 2, p. 52-57, 2006.

LÜ, F. et al. Application of advanced techniques for the assessment of bio-stability of biowastederived residues: A minireview. Bioresource Technology, v. 248, p. 122-133, 2018. https://doi.org/10.1016/j.biortech.2017.06.045

MANDAL, P. et al. Review on landfill leachate treatment by electrochemical oxidation: Drawbacks, challenges and future scope. Waste Management, v. 69, p. 250-273, 2017. https://doi.org/10.1016/j.wasman.2017.08.034 
MCBEAN, E. A.; ROVERS, F. A.; FARQUHAR, G. J. Solid waste landfill engineering and design. New Jersey: Prentice-Hall PTR, 1995.

MOHAMMAD-PAJOOH, E.; WEICHGREBE, D.; CUFF, G. Municipal landfill leachate characteristics and feasibility of retrofitting existing treatment systems with deammonification - A full scale survey. Journal of Environmental Management, v. 187, p. 354-364, 2017. https://doi.org/10.1016/j.jenvman.2016.10.061

MOROZESK, M. et al. Effects of humic acids from landfill leachate on plants: An integrated approach using chemical, biochemical and cytogenetic analysis. Chemosphere, v. 184, p. 309-317, 2017. https://doi.org/10.1016/j.chemosphere.2017.06.007

PEIXOTO, A. L. C. et al. Prediction of chemical oxygen demand in mature landfill leachate doped with Fenton's reagent, using empirical mathematical model obtained by full factorial design. Química Nova, v. 31, n. 7, 2008. http://dx.doi.org/10.1590/S010040422008000700008

PENG, Y. Perspectives on technology for landfill leachate treatment. Arabian Journal of Chemistry, v. 10, p. S2567-S2574, 2017. https://doi.org/10.1016/j.arabjc.2013.09.031

PEREIRA, J. A. et al. Walnut (Juglans regia L.) leaves: Phenolic compounds, antibacterial activity and antioxidant potential of different cultivars. Food and Chemical Toxicology, v. 45, n. 11, p. 2287-2295, 2007. https://doi.org/10.1016/j.fct.2007.06.004

SALAZAR, R. F. S.; ALCÂNTARA, M. A. K. DE; IZÁRIO FILHO, H. J. Evaluation of sample preparation methods and optimization of nickel determination in vegetable tissues. Revista Brasileira de Ciência do Solo, v. 35, n. 1, p. 241-248, 2011a. http://dx.doi.org/10.1590/S0100-06832011000100022

SALAZAR, R. F. S.; CARROCCI, J. S.; IZÁRIO FILHO, H. J. Employment of factorial design to evaluate the organic loading and aeration of biological systems in the degradation of dairy wastewater. Revista Ambiente \& Água, v. 6, n. 3, p. 98-109, 2011 b. https://doi.org/10.4136/ambi-agua.522

SÃO PAULO (Estado). Decreto no 8468 , de 8 de setembro de 1976. Prevenção e o controle da poluição do meio ambiente. Diário Oficial [do] Estado, São Paulo, p. 4, 9 set. 1976.

SILVA, T. F. C. V. et al. An innovative multistage treatment system for sanitary landfill leachate depuration: Studies at pilot-scale. Science of The Total Environment, v. 576, p. 99-117, 2017. https://doi.org/10.1016/j.scitotenv.2016.10.058

SILVA, T. F. C. V. et al. Scale-up and cost analysis of a photo-Fenton system for sanitary landfill leachate treatment. Chemical Engineering Journal, v. 283, p. 76-88, 2016. https://doi.org/10.1016/j.cej.2015.07.063

VAN TURNHOUT, A. G. et al. Theoretical analysis of municipal solid waste treatment by leachate recirculation under anaerobic and aerobic conditions. Waste Management, v. 71, p. 246-254, 2018. https://doi.org/10.1016/j.wasman.2017.09.034

VON SPERLING, M. Introdução à qualidade das águas e ao tratamento de esgotos. 3. ed. Belo Horizonte: UFMG, 2005.

WISZNIOWSKI, J. et al. Solar photocatalytic degradation of humic acids as a model of organic compounds of landfill leachate in pilot-plant experiments: influence of inorganic salts. Applied Catalysis B: Environmental, v. 53, n. 2, p. 127-137, Oct. 2004. https://doi.org/10.1016/j.apcatb.2004.04.017 
XIAOLI, C. et al. Spectroscopic studies of the effect of aerobic conditions on the chemical characteristics of humic acid in landfill leachate and its implication for the environment. $\begin{array}{lllllll}\text { Chemosphere, } & \text { v. } & 91, & \text { n. } & \text { 7, } & \text { p. }\end{array}$ https://doi.org/10.1016/j.chemosphere.2013.01.052

ZHANG, C. et al. Degradation of refractory organics in biotreated landfill leachate using high voltage pulsed discharge combined with $\mathrm{TiO} 2$. Journal of Hazardous Materials, v. 326, p. 221-228, 2017a. https://doi.org/10.1016/j.jhazmat.2016.12.034

ZHANG, W. et al. Optimization for zeolite regeneration and nitrogen removal performance of a hypochlorite-chloride regenerant. Chemosphere, v. 178, p. 565-572, 2017b. https://doi.org/10.1016/j.chemosphere.2017.03.091 